\title{
Conservation Of Symphytum Officinale L. At Cmprh Garden, Emerald
}

\author{
A.Vanitha ${ }^{a^{*}}$, R. Kavinprashanth ${ }^{\mathrm{a}}$, S. Mugendhiran ${ }^{\mathrm{a}}$, J.Shashikanth ${ }^{\mathrm{a}^{* * *}}$
}

$\mathrm{a}, \mathrm{a}^{*}, \mathrm{a}^{* *}$ Centre of Medicinal Plants Research in Homoeopathy, Indira Nagar, Emerald, The

Nilgiris, Tamilnadu, India

Corresponding author: email id $\quad-$ jaleshashikanth2000@gmail.com and

ajjanvanitha@gmail.com

\section{Abstract}

Symphytum L. commonly called as comfrey, belongs to the family Boraginaceae. The genus of Symphytum L. have a great medicinal value and used to treat a wide variety of ailments viz., bronchial problems, sprains, broken bones, arthritis, acne and skin conditions whereas pharmacological effects of comfrey extracts are endorsed to several chemical compounds. In view of above point, the present study of Survey, Collection and Documentation of Symphytum species, were carried out in different places of India. The rhizomes of Symphytum species were collected from Mynala village of Nilgiris, subsequent survey were carried out to IIIM Chatha Research Farm Jammu Tawi during 2017-2018 and it was grown at CMPRH garden, Emerald to confirm the identification of plants species. This specimen was collected and preserved herbarium at CMPRH garden Emerald for future reference. Among plants parts roots and leaves are mostly used for homeopathic system of medicine and this species were maintained and reproduces subsequent year by seed and root fragments. Root cuttings are the least expensive method of propagation. In addition to that Performance of Symphytum officinale at Nilgiris conditions were observed and the results revealed that Symphytum officinale L. is an erect, perennial herb with thick root stock. Leaves oblong-lanceolate and flowers are blue in colour. The data on length of root ranged from 10-20 cm with black to brown colour. Similarly, the length of lower, middle and upper cauline leaves ranged from 32.3-37.2 cm, 25.2-27.8cm, 10.4$13.2 \mathrm{~cm}$, respectively Whereas the width of the lower, middle, upper leaves ranged $12.5-17.4 \mathrm{~cm}$, 7.6- $10.2 \mathrm{~cm}, 3.4-4.1 \mathrm{~cm}$, respectively. Further, the studies on Symphytum officnale regarding root yield, dry matter ratio of leaves and roots as well as physiochemical properties other chemical compounds present and uses in homoeopathic system of the medicine under the Nilgiris condition are need to be studied elaborately in future.

Key words: Comfrey, Performance, Chemical properties, Conservation and Herbarium 


\section{INTRODUCTION}

Comfrey botanically called as Symphytum L. which derived from the Latin word means "grow together", reveal that the early uses of this plant (Teynor et al., 1997). The other common name of the world is "black-wort" (Gledhill, 2002), Asses-ears, Boneset, Bruise wort, Consolida, Consound, Gum plant, Knitback, Knit-bone, Slippery-root. Symphytum L. belongs to the family, Boraginaceae which are biennial or perennial herbs, shrubs or trees, usually with hairs especially on the leaves. Borginaceae is one of the largest angiosperm family; comprises approximately 2000 species and almost 100 genera distributed throughout the worldwide (Taia, 2006). According to Hilger et al.,2004 Boraginaceae family comprises to 131 genera including 2500 species. The species of this family occur in dry, open habitats and mountains valleys.

Economic importance of Boraginaceae family has a great value in medicinal plants and this family has a valuable compound such as pyrrolizidine alkaloids (Wollenweber et al., 2002). Correspondingly, the genus of Symphytum L. have a great medicinal value and used to treat a wide variety of ailments viz., bronchial problems, sprains, broken bones, arthritis, acne and skin conditions (Gomes et al., 2007). Leaf and root of Symphytum species are used by public, herbalists and physicians for treatment of broken bones, tendon damage, ulcerations in the gastrointestinal tract, and lung congestion, these species are also rich in many crucial nutrients, such as protein, antioxidant, vitamins especially vitamin $\mathrm{B}_{12}$, and are common component in the diet of certain ethnic groups (Rode, 2002).

Symphytum officinale contains five groups of major compounds which are carbohydrates (mucilage 29\%), purine derivatives, triterpenes, polyphenols, and pyrrolizidine alkaloids. Purine derivatives (PD) are degradation products from purines, purine bases and purine nucleosides. In this group, allantoin, a diureide of glyoxylic acid, is the major compound in a range of 0.6 4.7\%. In wound healing, allantoin regulates the inflammatory response and stimulates the fibroblastic proliferation and the extracellular matrix synthesis resulting in a faster reestablishment. Allantoin has been claimed as the active ingredient of comfrey, which is responsible for triggering cell division and would healing, also promoting conjunctive tissue, bone and cartilage growth (Neagu et al.2010). S. offcinale root extract contains allantoin and phenolic acids (e.g., rosmarinic, p-hydroxybenzoic, caffeic, chlorogenic and p-coumaric acids), and displays remarkable antioxidant effects, besides to exert a positive impact in human skin 
fibroblasts (Sowa et al.2018). Moreover, the strong antioxidant effects have been linked to polysaccharides, having a uronic acid group in the comfrey root (Chen et al.2018).

Comfrey extracts, ointments or compress pastes are applied externally, while leaf, herb or root have been traditionally used for musculoskeletal disorders, wounds, gout, hematomas and thrombophlebitis reported by Staiger et al.(2012). According to Singh et al. (2018) S. offcinale leaf extract loaded silver nanoparticles has been suggested to be used as an agent against skin photoaging due to its photoprotective potential. In addition to the antifungal activity of comfrey, its antibacterial activity against the bacteria causing bovine mastitis has also been reported (Avancini et al.2008). Indeed, Oliveira et al.2016 introduced S. offcinale in the broiler diet and found that it could be used as a growth-promoting antibiotic for feeding broiler.

According to Teynor et al.,(1997), Comfrey produces large amounts of foliage. This crop has been used as a salad green and potherb because it was considered a good source of protein and a rare plant-derived source of vitamin $\mathrm{B}_{12}$. Greeks and Romans used comfrey to stop heavy bleeding, treat bronchial problems, and heal wounds and broken bones. Wild comfrey was brought to America by English immigrants for medicinal uses. The allantoin content of comfrey, especially in the root, has resulted in its use in folk medicine for healing wounds, sores, burns, swollen tissue, and broken bones. Wounds and burns seemed to heal faster when allantoin was applied due to a possible increase in number of white blood cells. Comfrey has been reported to promote healthy skin with its mucilage content that moisturizes and soothes, while the allantoin promotes cell proliferation. The allantoin applied to external wounds is either a $0.4 \%$ solution or a $2 \%$ ointment. An effective allantoin formulation is difficult to prepare from comfrey due to the low and variable content of this substance. Hart (1976) reported that dried comfrey leaves contain 0.1 to $1.6 \%$ allantoin while dried roots have 0.4 to $1.5 \%$. Protein content of comfrey dry matter (15 to 30\%) is about as high as legumes. Robinson (1983) reported specific amino acid and mineral content of comfrey.

On the subject of medicinal value of Symphytum L. species which include around 35 species, viz., Symphytum offcinale L., Symphytum tuberosum L., Symphytum x uplandicum Nyman (Quaker, Russian, or blue comfrey) and it has originated as a natural hybrid of $S$. officinale L. and S. asperum Lepechin., Symphytum asperum Lepech (Prickly or rough comfrey) and Symphytum caucasicum Bieb (Schmelzer et al.2008 and Horinouchi et al.2013). Among all Symphytum species available $S$. offcinale is the most commonly used species and other species 
are Symphytum asperum (prickly comfrey) and S. uplandicum (Russian comfrey, syn. Symphytum peregrinum) have also been used (Frost et al.2013).

Realizing the importance of Symphytum officinale species in AYUSH system of medicine in particular with Homoeopathic system of treatment and presence of chemical composition along with their uses in phytopharmacology, the present research work was therefore undertaken with following objectives.

1. Survey, Collection and Documentation of Symphytum species

2. Identification, Introduction and Conservation of Symphytum officinale species at CMPRH garden, Emerald, The Nilgiris.

\section{MATERIALS AND METHODS}

CMPRH, this is the only center for Survey, Collection and Cultivation of Homoeopathic medicinal plants in India under Central Council for Research in Homoeopathy, Ministry of AYUSH, Government of India, New Delhi, which is situated in the South West of Udhagamandalam in Emerald, very near the Westside of Avalanche Reservoir Forest (Latitude $110,18^{\prime}$ and $110,41^{\prime}$ and Longitude $760,37^{\prime}$ and 760 , 49'E), altitude ranging from 1970m (near office) to 2028 above MSL. Total altitude difference is 58 meters. Nilgiri district with its wide range of agroclimatic conditions form a suitable land for the cultivation and maintenance of several medicinal plants. Long period of intensive Survey and the study of plants availability in India they found Nilgiri District is the best environmental conditions to introduce cultivate and conserve many exotic plants species which is used in Homoeopathic system of medicine, the study of Survey, Collection, Documentation (Herbarium) and conservation of Symphytum officinale were carried out during 2017-2018 in different places of India. Plants species were identified and Medicinal uses reported with the help of Materia Medica's (Clarke, 1982).

\section{RESULTS AND DISCUSSION}

\subsection{Objective 1: Survey, Collection and Documentation of Symphytum species}

The rhizomes of Symphytum officinale was collected from private garden near Mynala village of Nilgiris, subsequent survey was carried out to IIIM Chatha Research Farm Jammu Tawi during 2017-2018. This specimen was collected and preserved by means of herbarium at CMPRH garden Emerald as per procedure given by Jain and Rao,1977.

\section{Preparation of herbarium:}

The preparation of the specimens was followed by methods stated in Jain and Rao, 1977. 


\subsection{Collection:}

The plant specimen was collected as whole along with leaves, flowers and roots. After collection of specimen should put into the collection bag. Then the specimens mounted in $28 \mathrm{~cm}$ x $42 \mathrm{~cm}$ size card sheet. The mounted specimens were kept in between the iron frames. A very important part of the plant collection work is the record of field notes. Detailed notes should be entered in the field note book at the time of collection in the field itself. Usually a field note book has 100 leaves and the pages are serially numbered (called field numbers) to be suffixed to the collector's name, when cited.

\subsection{Poisoning and drying the specimen}

The specimens are poisoned either immediately after collection. It kills the plant and thereby the formation of abscission layer is prevented. The poisoning is generally done by dipping the whole plant in a saturated solution of mercuric chloride in ethyl alcohol. The plant is again put between the blotters in the presser till it gets completely dried. Mercuric chloride is corrosive for metals, and hence enamel trays and disposable gloves are used. All parts of the plant are dipped in the solution and left there for 15-20 seconds, depending upon the thickness of the plant, after dipping the specimens are again placed on a blotter for drying out the excess solution. Mercuric chloride is a deadly poisonous chemical and its effect on human beings is cumulative; hence much more care should be taken while poisoning.

\subsection{Mounting and labeling:}

After the specimen is pressed, dried and poisoned, it is affixed (along with a label) on a mounting sheet. The aim of the mounting is that the specimens should be neatly and uniformly spread and fixed on the sheet, this is achieved by pasting specimens to sheet with glue. The sheet is usually stiff and flexible so as to prevent damage during the handling of mounted specimens. The common technique is pasting specimens to sheet with natural glue. Then, with the help of a small or large brush, depending on the size of the plant, the glue is applied to all parts of specimen. The specimen is slowly lifted with the help of forceps or hands and placed on the mounting board. This method is very common in our country and is more rapid and economical. The mounting sheet with specimens kept in press for one day for proper sticking and drying. Herbarium label is fixed on the bottom right hand corner about $1 \mathrm{~cm}$ away from edges of the mounting sheet. After gluing the specimens and pasting the labels, the data on the labels should be entered clearly with some permanent ink or preferably types before pasting. The herbarium 
specimen sheet is now ready for deposition/reposition in the one of the indexed herbaria for the plant identification (Fig 1.)

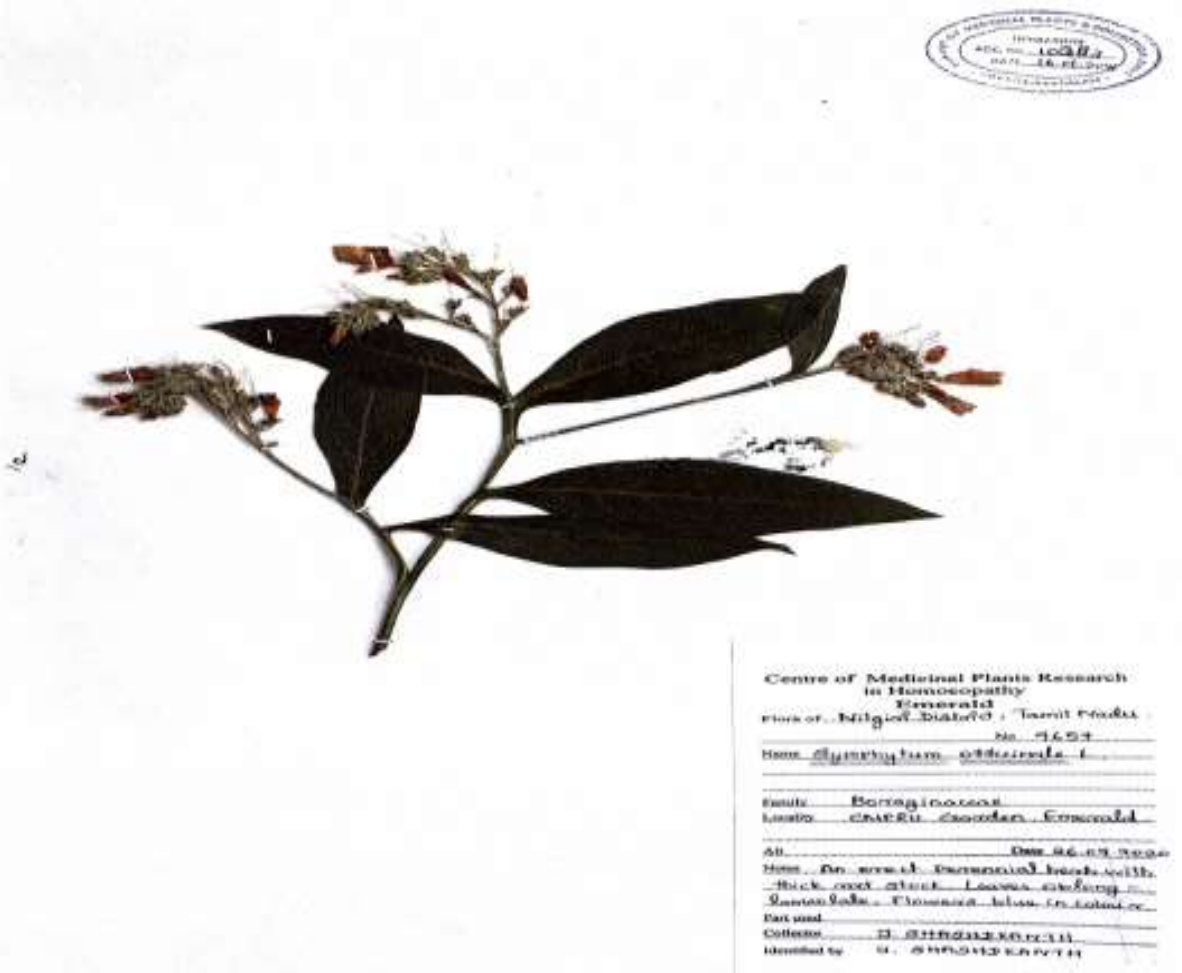

Fig.1. Herbarium of Symphyttum officinale L.

\subsection{Objective 2: Conservation of Symphytum officinale 1. at CMPRH garden}

This study used to exemplify and evaluate the taxonomic significance of morphological features of the genus Symphytum officinale L.belonging with Boraginaceae (Fig 2.)

3.5.1. Distribution : Symphytum officinale L., is native to England and extends throughout most of Europe into Central Asia and Western Siberia. Cultivated in great Britain and united states. 


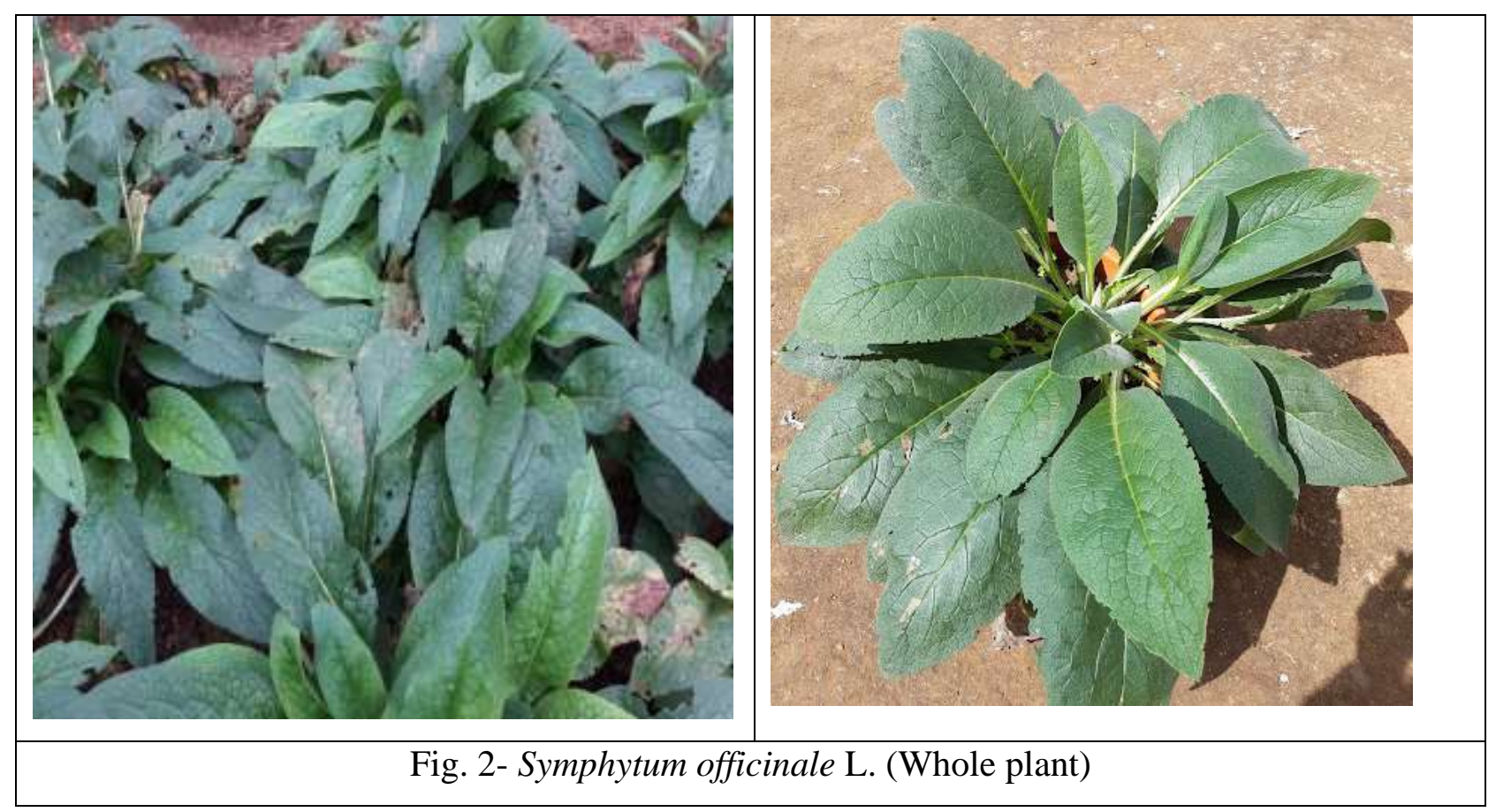

\subsubsection{Description:}

It is a perennial herb grow up to $1 \mathrm{~m}$ in height with tuberous, thick roots, stem branched, white pilose. Leaves slightly pilose, basal and lower cauline, ovate-lanceolate, upper oblonglanceolate, all broadly decurrent at base. Leaves of Symphytum officinale L.species are oblong lanceolate, Basal leaves are large, lance-shaped, stalked, and coarsely hairy. The shape of lower cauline leaves in the genus Symphytum are elliptic, elliptic to ovate bases cuneate and the margin are entire but the length ranged between $32.3-37.2 \mathrm{~cm}$ width ranged between $12.5-17.4 \mathrm{~cm}$ while the petiole length ranged between $14.2-16.5 \mathrm{~cm}$ Middle cauline leaves are ovate to lanceolate, elliptic to lanceolate, margin while the length ranged between $25.2-27.8 \mathrm{~cm}$ width ranged between $7.6-10.2 \mathrm{~cm}$ length petiole ranged between $14.6 .5-17.1 \mathrm{~cm}$. The shape of upper cauline leaves in the genus Symphytum are elliptic, elliptic to ovate, acute apex, margin entire, while the length ranged between $10.4-13.2 \mathrm{~cm}$ with width ranged between $3.4-4.1 \mathrm{~cm}$ and the petiole length ranged from 7.5- $8.4 \mathrm{~cm}$. Plant spread also important growth for leaf and root yield. The plant spread ranged from 76.5 - $80.4 \mathrm{~cm}(\mathrm{NS})$ and 63.5- $65 \mathrm{~cm}$ (EW) (Table 1.).

\subsubsection{Part used: Root.}

Macroscopical: Cylindrical pieces of about 10 to $40 \mathrm{~mm}$ in length and 5 to $10 \mathrm{~mm}$ in diameter, externally nearly black and exhibits glistening crystals on the surface, strongly wrinkled longitudinally. Fracture short: fractured surface greyish-white and horny. The smoothened 
transverse surface shows a narrow bark separated by a dark cambium line from the radiate wood possessing wide xylem rays. Odourless; taste mucilaginous.

3.5.4. Flower: The bell-shaped flowers with pedicels are in terminal drooping cymes or onesided clusters. Flowers are blue in colour and 5- Sepals, 5- petals, 5 stamens, ovary 4 -lobed, nutlets 4, obliquely ovoid, erect, rugose fused into a bell shape. Flowering starts in late May or early June.(Fig.4).

Table 1. Performance of Symphytum officinale L.at CMPRH garden, Emerald

\begin{tabular}{|c|c|c|c|c|c|c|c|c|c|}
\hline \multirow{4}{*}{ Leaves } & \multicolumn{3}{|c|}{ Lower Leaf } & \multicolumn{3}{|c|}{ Middle Leaf } & \multicolumn{3}{|c|}{ Upper Leaf } \\
\hline & $\begin{array}{l}\text { Length } \\
(\mathrm{cm})\end{array}$ & $\begin{array}{l}\text { Width } \\
(\mathrm{cm})\end{array}$ & $\begin{array}{l}\text { Petiole } \\
\text { length } \\
(\mathrm{cm})\end{array}$ & $\begin{array}{l}\text { Length } \\
(\mathrm{cm})\end{array}$ & $\begin{array}{l}\text { Width } \\
\text { (cm) }\end{array}$ & $\begin{array}{l}\text { Petiole } \\
\text { length } \\
(\mathrm{cm})\end{array}$ & $\begin{array}{l}\text { Length } \\
(\mathrm{cm})\end{array}$ & $\begin{array}{l}\text { Width } \\
(\mathrm{cm})\end{array}$ & $\begin{array}{l}\text { Petiole } \\
\text { length } \\
(\mathrm{cm})\end{array}$ \\
\hline & $32.3-$ & $12.5-$ & $14.2-$ & $25.2-$ & $7.6-$ & $14.6 .5-$ & 10.4 & $3.4-$ & $7.5-$ \\
\hline & 37.2 & 17.4 & 16.5 & 27.8 & 10.2 & 17.1 & 13.2 & 4.1 & 8.4 \\
\hline Plant & \multicolumn{9}{|c|}{$(76.5-80.4)(\mathrm{NS})$} \\
\hline $\begin{array}{c}\text { spread } \\
(\mathrm{cm})\end{array}$ & \multicolumn{9}{|c|}{$63.5-65)(\mathrm{EW})$} \\
\hline $\begin{array}{c}\text { Root } \\
\text { length } \\
(\mathrm{cm})\end{array}$ & \multicolumn{9}{|c|}{$10.5-18.5$} \\
\hline
\end{tabular}

NS-North South, EW- East West

\subsection{Cultural Practices}

3.6.1. Soil and Climate: Comfrey is growing well in moist and fertile soils. It grows in temperate and subtropical region. It gives maximum yield under cold conditions with full sunlight. Due to its deep system, the plant can withstand drought.

3.6.2. Propagation: Common comfrey was maintained and reproduces subsequent year by seed and root fragments. Root cuttings are the least expensive method of propagation and consequently, are used most often. Root cuttings from $1 \frac{1}{2}$ to 6 inches long and from $1 / 4$ to $3 / 4$ in diameter are common. Even smaller pieces will generate plants, but longer pieces are more certain to establish and emerge faster. Root cuttings should be planted before September and should be planted in flat and covered with soil. The root cuttings should be planted at a depth of 2 to 4 in. Spacing should be 30 x $30 \mathrm{~cm}$. The root system of Symphytum officinale L.species with tap roots system length ranged from $10-20 \mathrm{~cm}$ and fibrous roots with black to brown color (Fig. 3). 
3.6.3. Planting: the best time for comfrey planting is April, but the crop can be planted throughout the growing season. Planting depth varies with soil texture and soil moisture content. $4 \mathrm{~cm}$ depth is common, but upto $2 \mathrm{~cm}$ depth is also practiced with an adequate irrigation system.

3.6.4. Irrigation: Plant should be irrigated regularly for better establishment

3.6.5. Fertilizer: Plant can response well to manures like compost or vermicompost

( 5 tonnes/ha) should applied by broadcasting before planting or during field preparation.

3.6.6.Weeding: Comfrey is an excellent weed competitor due to its rapid and dense growth. Hand hoeing require after one month of planting.

3.6.7. Harvesting: Mature comfrey can be harvested 4-5 times per year. The optimum period of cut the crop is just before flowering.

3.6.8. Yield: Annual dry weight yield is 2 to $6 \mathrm{t} / \mathrm{ha}$.

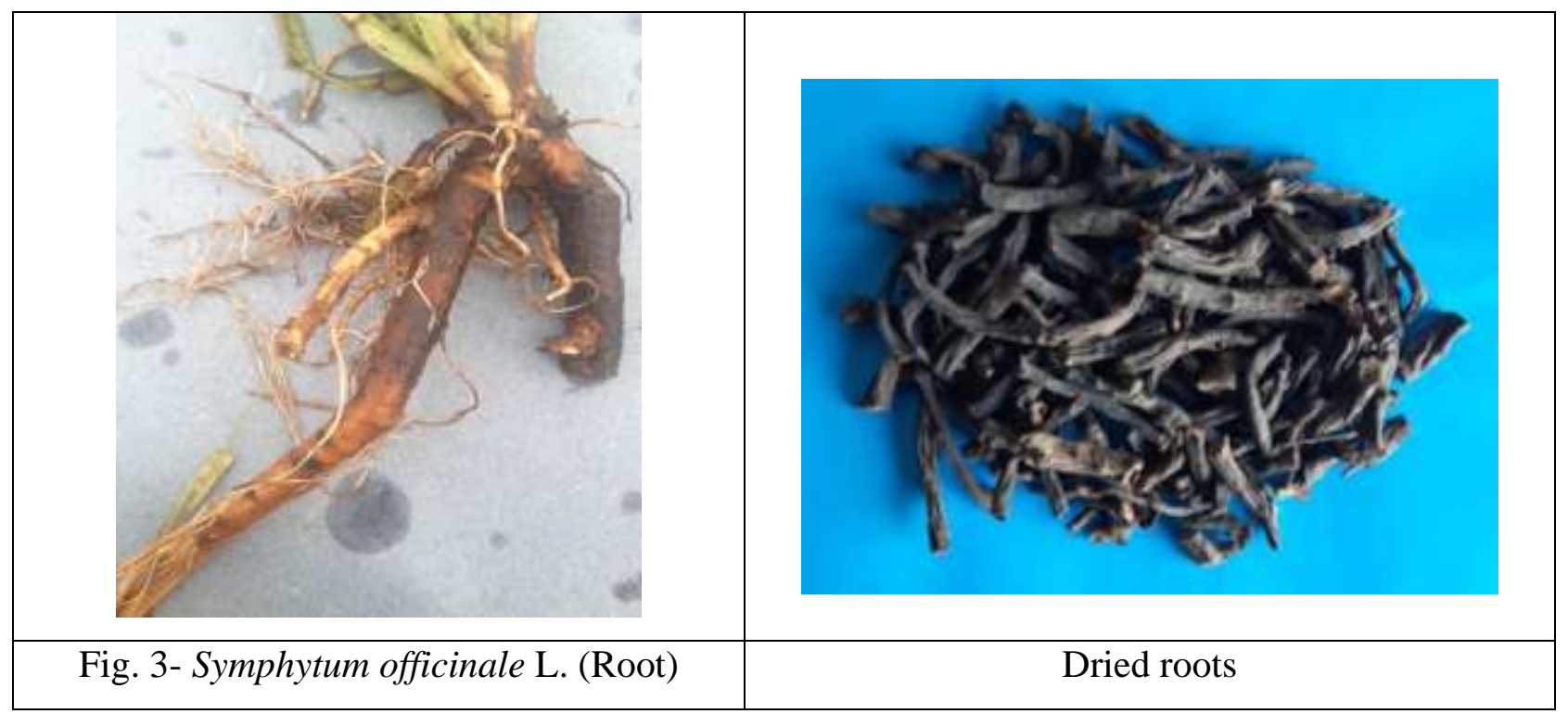




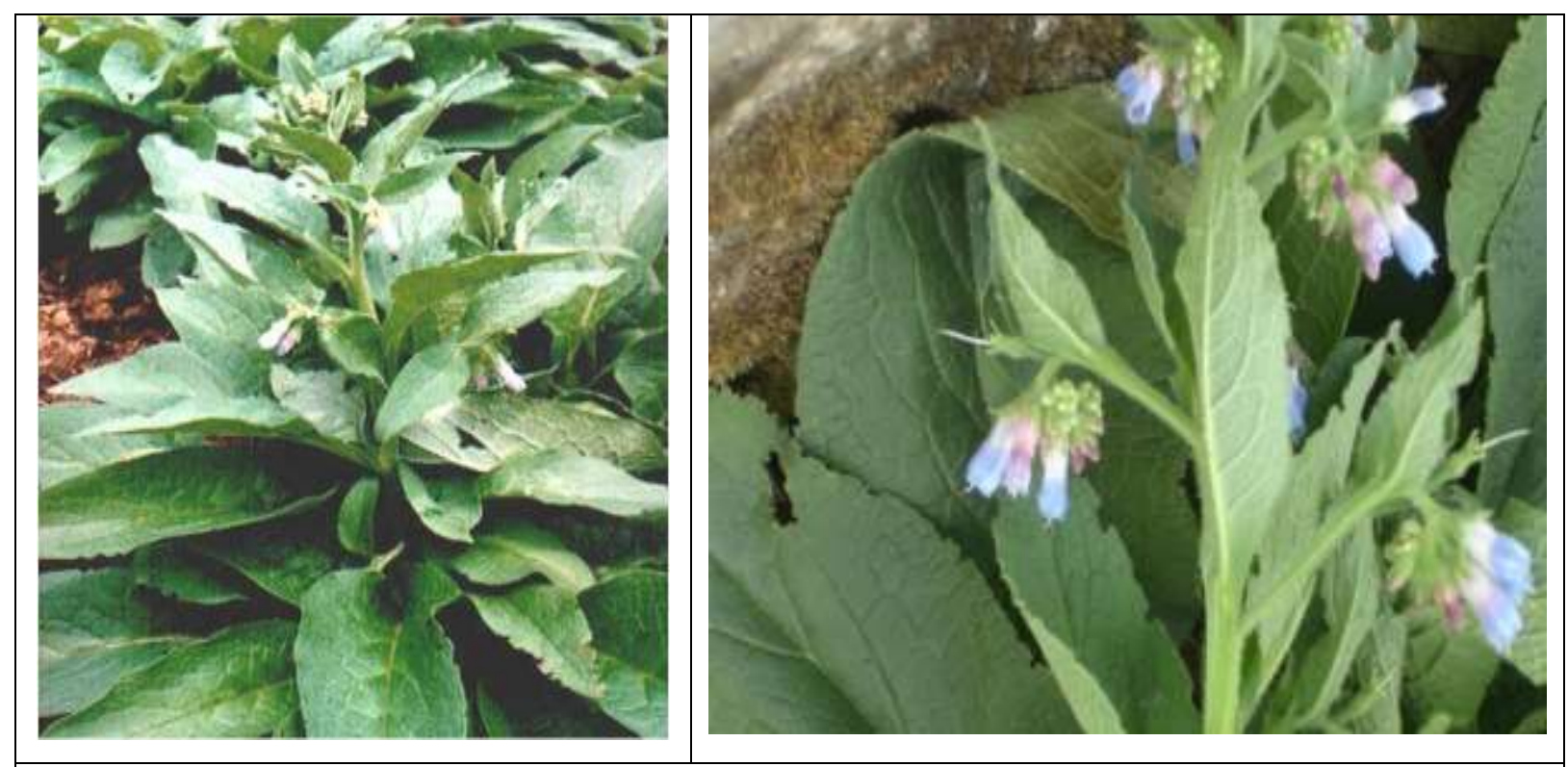

Fig.4 - Symphytum officinale L. (Flower)

\section{Conclusion}

The present study of the Symphytum officinale L. was distributed in the Euro-Siberian and Mediterranean regions. The genus Symphytum L. have a great medicinal value and used to treat a wide variety of ailments viz., bronchial problems, sprains, broken bones, arthritis, acne and skin conditions. These species are also rich in many crucial nutrients, such as protein, antioxidant, vitamins especially vitamin B12, and are common component in the diet of certain ethnic groups. On the subject of medicinal value of Symphytum L. species which include around 35 species. Among all Symphytum species available S. offcinale is the most commonly used species. With the aim of Survey, Collection and Documentation of Symphytum species, survey was carried out during 2017-2018 in different places in India. Whereas, Nilgiri district with its wide range of agroclimatic conditions forms a cradle land for the cultivation and maintenance of several medicinal plants. This study used to illustrate and assess the taxonomic significance of morphological features of the genus Symphytum officinale L.belonging with Boraginaceae. In this paper discussed about the Symphytum sp. with little information on research strategies. Thus, further studies are needed to provide more in-depth data on Symphytum officinale growth and yield and physiochemical properties of Symphytum officinale also need to study under Nilgiris condition. 


\section{Reference}

1. C. Avancini, J.M. Wiest, R. Dall'Agnol, J.S. Haas, G.L. Von Poser, Am. J. Pharm. 27, 894 (2008).

2. S. Chen, H. Shang, J. Yang, R. Li, H. Wu, Ind. Crop. Prod. 121, 18 (2018).

3. J.H. Clarke, Dictionary of Practical Materia Medica. New Delhi: Jain Publishing Company.(1982).

4. R. Frost, H. MacPherson, S.M. O’Meara, Complem.Ther. Med. 21, 724 (2013).

5. M.F. Gomes, C.O. Massoco, J.G. Xavier, Evid Based Complement Alternat. Med. 7, 197, (2010).

6. H.H. Hilger, F. Selvi, A. Papini, M. Bigazzi Molecular systematics of Boraginaceae tribe Boragineae based on ITS1 and trnL sequences,(2004).

7. C.D. Horinouchi, M.F. Otuki, Botanical briefs: comfrey (Symphytum o_cinale). Cutis , 91, 225 (2013).

8. S.K. Jain, R.R.Rao, A handbook of Field and Herbarium Methods. Today's and Tomorrow's printers and publishers. NewDelhi.1977.

9. E. Neagu, G. Paun, G. Radu, Rom. Biotechnol. Lett. 15, 5505 (2010).

10. Robinson, Comfrey - A controversial crop. Minneosta report. Agricultural experimental station, University of Minnesota, 1983.

11. D. Rode, Trends Pharmacol. Sci. 23, 497 (2002).

12. P. Rodrigues Oliveira, F. Ramos Santos, E. Ferreira Duarte, G. Silva Guimarães, N. Sartori Carvalho Mattos, C. Minafra, Semin.: Ciências Agrárias 37, 2677, (2016).

13. G. Schmelzer, A. Gurib-Fakim, Plant Resources of Tropical Africa: Medicinal Plants 1; Backhuys Publishers CTA: Kerkwerve, The Netherlands, 2008.

14. H. Singh, J. Du, P. Singh, T.H. Yi, J. Nanostructure Chem. 8, 359 (2018).

15. I. Sowa, R. Paduch, M. Strzemski, S. Zieli`'nska, E. Rydzik-Strzemska, J. Sawicki, R. Kocjan, J. Polkowski, A. Matkowski, M. Latalski, Nat. Prod. Res. 32, 605 (2018).

16. C. Staiger Comfrey: a clinical overview. Phytother. Res. 26, 1441 (2012)

17. T.M. Teynor, D.H. Putnam, J.D. Doll, K.A. Kelling, E.A. Oelke, D.J. Undersander, E.S. Oplinger . Comfrey alternative field crops manual, 1997.

18. W.K. Taia, Asian J. Plant Sci., 3: 441-454 (2006). 
19. E.R. Wollenweber, M. Wehde, M.Dörr, J. Stevens, Flavonoid Aglycones in Boraginaceae, (2002)

20. Augustine and Kishore, Homoeopathic Pharmacopoeia of India. $I^{\text {st }}$ edition $3^{\text {rd }}$ Vol.1978. 